\title{
IN VITRO ANTIBACTERIAL ACTIVITY OF THE CRUDE METHANOL EXTRACT OF WOODFORDIA FRUTICOSA KURZ. FLOWER (LYTHRACEAE)
}

\author{
Jigna Parekh; Sumitra Chanda* \\ Phytochemical, Pharmacological and Microbiological Laboratory, Department of Biosciences, Saurashtra University, Rajkot, \\ Gujarat, India
}

Submitted: June 05, 2006; Returned to authors for corrections: September 04, 2006 Approved: February 12, 2007.

\begin{abstract}
The antibacterial activity of the crude methanol extract of Woodfordia fruticosa Kurz. flower was evaluated at two different concentrations by the agar well diffusion method. The methanol extract of the flower exhibited antibacterial activity at varied levels except against Bacillus subtilis and Micrococcus flavus. The methanol extract was most active against Pseudomonas pseudoalcaligenes. The extract was more active against Gramnegative bacteria as compared to Gram-positive. The inhibitory effect of the extract was compared with standard antibiotics, amoxicillin and ciprofloxacin.
\end{abstract}

Key words: Woodfordia fruticosa, antibacterial activity, crude methanol extract

\section{INTRODUCTION}

Herbal medicine represents one of the most important fields of traditional medicine all over the world. To promote the proper use of herbal medicine and to determine their potential as sources for new drugs, it is essential to study medicinal plants, which have folklore reputation in a more intensified way $(1,3,7,19)$. Over the past 20 years, there has been an increased interest in the investigation of natural materials as sources of new antibacterial agents. Different extracts from traditional medicinal plants have been tested to identify the source of the therapeutic effects. As a result some natural products have been approved as new antibacterial drugs, but there is still an urgent need to identify novel substances that are active towards pathogens with high resistance $(6,17)$.

Recently, multiple drug resistance has developed due to indiscriminate use of commercial antimicrobial drugs commonly used in the treatment of infectious diseases (20) making it a global growing-problem. Isolation of microbial agents less susceptible to regular antibiotics and recovery of increasing resistant isolates during antibacterial therapy is rising throughout the world which highlights the need for new principles (21). Natural products of higher plants may give a new source of antimicrobial agents with possibly novel mechanisms of action $(4,9,13,14)$. Contrary to the synthetic drugs, antimicrobials of plant origin are not associated with many side effects and have an enormous therapeutic potential to heal many infectious diseases (10). For example, vincristine (an antitumor drug), digitalis (a heart regulator), and ephedrine (a bronchodilator used to decrease respiratory congestion) were all originally discovered through research on plants. Salicylic acid, a precursor of aspirin, was originally derived from white willow bark and the meadowsweet plant and digoxin was derived from foxglove. Cinchona bark is the source of malaria-fighting quinine. Vincristine, used to treat certain types of cancer, comes from periwinkle. The opium poppy yields morphine, codeine and paregoric, a treatment for diarrhoea (8).

This paper reports the first attempt to study the antimicrobial activity of Indian medicinal plant, Woodfordia fruticosa (Lythraceae) against an array of human pathogens. The crude methanol extract of the flower of Woodfordia fruticosa was evaluated for the potential antibacterial property. The selection of this plant for evaluation was based on its traditional usage. The flowers of this plant posseses high content of tannins and they have astringent, acrid, refrigerant, stimulant, styptic, uterine sedative, anthelmintic, constipating, antibacterial, vulnerary,

*Corresponding Author. Mailing address: Phytochemical, Pharmacological and Microbiological Laboratory - Department of Biosciences - Saurashtra University - Rajkot, 360 005, Gujarat, India. E-mail: sumitrachanda@yahoo.com 
alxeteric and febrifuge properties (2). The previously isolated classes of constituents from Woodfordia fruticosa flower are ellagitannin dimmers (24) with astringent and haemostatic properties that affect histamine release. It is used in menorrhagia and leucorrhoea; another constituent isolated was woodfordin C (12) with antitumor activity (5). An extract of the plant was found to stimulate the contraction of the intestinal loop, and investigations have corroborated the clinical use of the drug in bowel complaints. The drug also shows antipyretic action which compares favorably with that of acetylsalicylic acid. The dried flowers are powdered and sprinkled over ulcers and wounds to diminish discharge and promote granulation (11).

\section{MATERIALS AND METHODS}

\section{Plant Material}

Woodfordia fruticosa Kurz. (Lythraceae) flowers were collected locally in August 2004 from Rajkot, Gujarat, India. The plant was identified by Dr. P. S. Nagar, Department of Biosciences, Saurashtra University, Rajkot (voucher specimen number PSN303). The dried flowers were homogenized to fine powder and further subjected to extraction.

\section{Crude Extraction}

The crude methanol extract was obtained by extracting $10 \mathrm{~g}$ of dried plant powder in $100 \mathrm{ml}$ methanol and kept on a rotary shaker for $24 \mathrm{~h}$. The extract was filtered, centrifuged at $5000 \mathrm{~g}$ for $15 \mathrm{~min}$. and was dried under reduced pressure. The yield obtained for crude methanol extract was $20.93 \%$ with respect to the initial dry material. The extract was stored at $4^{\circ} \mathrm{C}$ in airtight bottles.

\section{Microorganisms Tested}

The bacterial strains used to assess the antibacterial properties of crude methanol extract of Woodfordia fruticosa included six Gram-positive and nine Gram-negative bacteria (Table 1). The investigated microbial strains were obtained from National Chemical Laboratory (NCL), Pune, India. The organisms were maintained on nutrient agar (Hi Media, India) slope at $4^{\circ} \mathrm{C}$ and sub-cultured before use. The bacteria studied are clinically important ones causing several infections and it is essential to overcome them through some active therapeutic agents.

\section{Determination of Antibacterial Assay}

In vitro antibacterial activity of the crude methanol extract was studied against fifteen bacterial strains by the agar well diffusion method (15). Mueller Hinton agar no. 2 (Hi Media, India) was used as the bacteriological medium. The extracts were diluted in $100 \%$ dimethylsulphoxide (DMSO) at the concentrations of $5 \mathrm{mg} / \mathrm{mL}$ and $2.5 \mathrm{mg} / \mathrm{mL}$. The antibacterial activity was evaluated at two different concentrations viz. 500 $\mu \mathrm{g} /$ well and $250 \mu \mathrm{g} / \mathrm{well}$. The Mueller Hinton agar was melted and cooled to $48-50^{\circ} \mathrm{C}$ and a standardized inoculum $\left(1.5 \times 10^{8}\right.$ CFU/mL, 0.5 McFarland) was then added aseptically to the molten agar and poured into sterile Petri dishes to give a solid plate. Wells were prepared in the seeded agar plates. The test compound $(100 \mu \mathrm{l})$ was introduced in the well $(8.5 \mathrm{~mm})$. The plates were incubated overnight at $37^{\circ} \mathrm{C}$. The antimicrobial spectrum of the extract was determined for the bacterial species in terms of zone sizes around each well. The diameters of zone of inhibition produced by the agent were compared with those produced by the commercial control antibiotics, amoxicillin ( 5 $\mathrm{mg} / \mathrm{mL})$ and ciprofloxacin $(5 \mathrm{mg} / \mathrm{mL}$; Table 1$)$. These are commonly used antibiotics to treat infections caused by several Gram positive and Gram negative bacteria. So they were selected as control antibiotics. For each bacterial strain controls were maintained where pure solvents were used instead of the extract. The control zones were subtracted from the test zones and the resulting zone diameter is shown in the Table 1 . The experiment was performed three times to minimize the error and the mean values are presented.

\section{RESULTS AND DISCUSSION}

The antibacterial activity of the crude methanol extract of the Woodfordia fruticosa was determined against fifteen bacterial strains which is reported in Table1.

The antibacterial activity was observed to be in dose dependent manner i.e. $5 \mathrm{mg} / \mathrm{mL}$ showed more level of activity than $2.5 \mathrm{mg} / \mathrm{mL}$ against all the tested microorganisms. Grampositive bacteria, B. subtilis and M. flavus were most resistant strains. Gram-negative bacteria P. mirabilis showed antibacterial activity at only one concentration i.e. $5 \mathrm{mg} / \mathrm{mL}$. The methanol extract of Woodfordia fruticosa was most active against $P$. pseudoalcaligenes in comparison to all the microorganisms tested. Gram-negative bacteria were more susceptible to the plant extract than Gram-positive bacteria which contradict the previous reports that plant extracts are more active against Grampositive bacteria than Gram-negative bacteria $(16,23)$. It is therefore theorized that Gram-positive bacteria are more susceptible than Gram-negative bacteria due to the differences in their cell wall structure. Gram-negative organisms are considered to be more resistant due to their outer membrane acting as a barrier to many environmental substances, including antibiotics (22). However, the results from this study reveals that the crude methanol extract of Woodfordia fruticosa contain certain constituents like tannins with significant antibacterial property which enables the extract to overcome the barrier in Gram-negative cell wall (18) The results can be compared with the standard antibiotics (Table 1).

From our investigation, the results obtained confirm the therapeutic potency of Woodfordia fruticosa used in traditional medicine. In addition, these results form a good basis for selection of the plant for further phytochemical and 
Parekh, J. and Chanda, S.

Table 1. Antibacterial activity of crude methanol extract of Woodfordia fruticosa flower by agar well diffusion method.

\begin{tabular}{lcccc}
\hline \multirow{2}{*}{ Microorganisms } & \multicolumn{4}{c}{ Inhibition Zone (mm)* } \\
\cline { 2 - 5 } & Woodfordia fruticosa & Amoxicillin & Ciprofloxacin \\
\cline { 2 - 5 } & $(5 \mathrm{mg} / \mathrm{mL})$ & $(2.5 \mathrm{mg} / \mathrm{mL})$ & $(5 \mathrm{mg} / \mathrm{mL})$ & $(2.5 \mathrm{mg} / \mathrm{mL})$ \\
\hline Bacillus cereus (ATCC 11778) & 16 & 14 & 15 & 14 \\
Bacillus subtilis (ATCC 6633) & - & - & 29 & 35 \\
Staphylococcus aureus (ATCC 25923) & 16 & 13 & 24 & 24 \\
Staphylococcus epidermidis (ATCC 12228) & 16 & 13 & 20 & 35 \\
Staphylococcus subflava (NCIM 2178) & 12 & 10 & 33 & 37 \\
Micrococcus flavus (ATCC 10240) & - & - & - & 15 \\
Alcaligenes fecalis (ATCC 8750) & 21 & 18 & - & 35 \\
Enterobacter aerogenes (ATCC 13048) & 20 & 17 & 25 & 30 \\
Klebsiella pneumoniae (NCIM 2719) & 20 & 18 & 36 & 38 \\
Proteus mirabilis (NCIM 2241) & 11 & - & 29 & 20 \\
Proteus vulgaris (NCTC 8313) & 20 & 17 & - & 29 \\
Pseudomonas aeruginosa (ATCC 27853) & 15 & 12 & - & 32 \\
Pseudomonas pseudoalcaligenes (ATCC 17440) & 24 & 22 & 29 & 46 \\
Pseudomonas testosteroni (NCIM 5098) & 19 & 16 & - & 30 \\
Salmonella typhimurium (ATCC 23564) & 18 & 14 & 13 & 22 \\
\hline
\end{tabular}

*: values include cup borer diameter $(8.5 \mathrm{~mm})$ and are mean of three replicates.

pharmacological investigation. The results of the present study supports the folkloric usage of the studied plant and suggests that the plant extract possess certain constituents with antibacterial properties that can be used as antimicrobial agents in new drugs for the therapy of infectious diseases caused by pathogens. The most active extracts can be subjected to isolation of the therapeutic antimicrobials and carry out further pharmacological evaluation.

\section{RESUMO}

\section{Atividade antibacteriana in vitro do extrato metanólico bruto da flor Woodfordia fruticosa Kurz. (Lythraceae)}

A atividade antibacteriana do extrato metanólico bruto da flor Woodfordia fruticosa Kurz. (Lythraceae) foi avaliada em duas concentrações diferentes através do método de difusão em poços. A atividade antibacteriana ocorreu em diferentes níveis, exceto contra Bacillus subtilis e Micrococcus flavus. O extrato metanólico foi mais ativo contra Pseudomonas pseudoalcaligens. O extrato foi mais ativo contra bactérias Gram negativas do que bactérias Gram positivas. $\mathrm{O}$ efeito inibitório do extrato foi comparado ao dos antibióticos padrão amoxicilina e ciprofloxacina.

Palavras-chave: Woodfordia fruticosa, atividade antibacteriana, extrato metanólico bruto

\section{REFERENCES}

1. Al-Dubai, A.S.; Al-Khulaidi, A.A.; (1996). Medical and aromatic plants of Yemen (in Arabic). Obadi Center for Studies and Publishing, Sana'a, Yemen.

2. Anjaria, J.; Parabia, M.; Dwivedi, S.; (2002). Ethnovet heritage Indian ethnoveterinary medicine - An Overview,; Pathik Enterprise, Ahmedabad (Gujarat), India.

3. Awadh Ali, N.A.; Juelich, W.D.; Kusnick, C.; Lindequist, U.; (2001). Screening of Yemeni medicinal plants for antibacterial and cytotoxic activities. J. Ethnopharmacol., 74, 173-179.

4. Barbour, E.K.; Al Sharif, M.; Sagherian, V.K.; Habre, A.N.; Talhouk, R.S.; Talhouk, S.N.; (2004). Screening of selected indigenous plants of Lebanon for antimicrobial acitivity. J. Ethnopharmacol., 93, $1-7$.

5. Cho, T.; Koshiur, R.; Miyamot, K.; Nitt, A.; Okud, T.; Yoshid, T.; (1990). Woodfordin C, a macro-ring hydrolyzable tannin dimer with antitumor activity, and accompanying dimers from Woodfordia fruticosa flowers. Chem. Pharm. Bull., 38, 1211-1217.

6. Cragg, G.M.; Newman, D.J.; Snader, K.M.; (1997). Natural products in drug discovery and development. J. Nat. Prod., 60, 52-60.

7. El-Faky, F.K.; Attif, O.; Aboul Ela, M.; Gaanem, N.; (1995). Antimicrobial evaluation of extracts from some Yemeni plants. Alexanderian J. Pharm. Sci., 9, 35-37.

8. Farnsworth, N.R.; Morris, R.W.; (1976). Higher plants: the sleeping giant of drug development. Am. J. Pharm., 48, 46-52.

9. Hamil, F.A.; Apio, S.; Mubiru, N.K.; Bukenya-Ziraba, R.; Mosango, M.; Maganyi, O.W.; Soejarto, D.D. (2003). Traditional herbal drugs of Southern Uganda, II: literature analysis and antimicrobial assays. J. Ethnopharmacol., 84, 57-78.

10. Iwu M.W.; Duncan A.R.; Okunji, C.O. (1999). New antimicrobials of plant origin In: Janick, J. (Ed.), Perspectives on New crops and New Uses. ASHS Press, Alexandria, VA, pp.457-462. 
11. Krishnan, P.N.; Seeni, S.; (1994). Rapid micropropagation of Woodfordia fruticosa (L.) Kruz (Lythraceae), a rare medicinal plant. Plant Cell Rep. 14, 55-58.

12. Kuramochi-Motegi, A.; Kuramochi, H.; Kobayashi, F.; Ekimoto, H.; Takahashi, K.; Kadota, S.; Takamori, Y.; Kikuchi, T. (1992). Woodfruticosin (woodfordin C) a new inhibitor of DNA topoisomerase II. Experimental antitumor activity. Biochem. Pharmacol., 44, 1961-1965.

13. Machado, T.B.; Pinto, A.V.; Pinto, M.C.F.R.; Leal, I.C.R.; Silva, M.G.; Amaral, A.C.F.; Kuster, R.M.; Netto-dosSantos, K.R.; (2003). In vitro activity of Brazilian medicinal plants, naturally occurring naphthoquinones and their analogues, against methicillin-resistant Staphylococcus aureus. Int. J. Antimicrob., 21, 279-284.

14. Motsei, M.L.; Lindsey, K.L.; van Staden, J.; Jaeger, A.K.; (2003). Screening of traditionally used South African plants for antifungal activity against Candida albicans. J. Ethnopharmacol., 86, 235241.

15. Perez, C.; Paul, M.; Bazerque, P.; (1990). An antibiotic assay by the agar-well diffusion method. Acta Biol. Med. Exp., 15, 113-115.

16. Rabe, T.; Van Staden, J. (1997). Antibacterial activity of South African plants used for medicinal purposes. J. Ethnopharmacol., $56,81-87$
17. Recio, M.C. (1989). A review of some antimicrobial compounds isolated from medicinal plants reported in the literature 1978-1988. Phytotherap. Res., 3, 1445-1453.

18. Scalbert, A. (1991). Antimicrobial properties of tannins Phytochemistry, 30, 3875-3883.

19. Schopen, A. (1983). Traditionelle Heilmittel in Jemen. Franz Steiner Verlag $\mathrm{GmbH}$, Berlin.

20. Service, R.F. (1995). Antibiotics that resist resistance. Science, 270, 724-727.

21. Shahidi, G.H.; Karimi Nik, A. (2004). Antibacterial activity of some medicinal plants of Iran against Pseudomonas aeruginosa and $P$. fluorescens. Asian J. Plant Sci., 3, 61-64.

22. Tortora, G.J.; Funke, B.R.; Case, C.L. (2001). Microbiology: an introduction. Benjamin Cummings, San Francisco, p.88.

23. Vlietinck, A.J.; Van Hoof, L.; Totte, J.; Lasure, A.; Vanden Berghe, D.; Rwangobo, P.C.; Mvukiyuniwami, J. (1995). Screening of hundred Rwandese medicinal plants for antimicrobial and antiviral properties. J. Ethnopharmacol., 46, 31-47.

24. Yoshida, T.; Chou, T.; Haba, K.; Okano, Y.; Shingu, T.; Miyamoto, K.; Koshiura, R.; Okuda, T. (1989). Camellin B and nobotanin I, macrocyclic ellagitanin dimmers and related dimmers, and their antitumor activity. Chem. Pharm. Bull., 37, 3174-3176. 